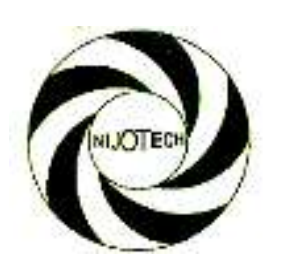

Nigerian Journal of Technology (NIJOTECH)

Vol. 38, No. 1, January 2019, pp. 93 - 98

Copyright@ Faculty of Engineering, University of Nigeria, Nsukka,

Print ISSN: 0331-8443, Electronic ISSN: 2467-8821 www.nijotech.com

http://dx.doi.org/10.4314/njt.v38i1.12

\title{
CHEMICAL AND MINERALOGICAL CHARACTERIZATION OF GIDAN JAJA IRON ORE, ZAMFARA STATE, NIGERIA
}

\author{
F. Asuke ${ }^{1, *}$, K. A. Bello ${ }^{2}$, M. A. Muzzammil ${ }^{3}$, D. G. Thomas ${ }^{4}$, K. Auwal ${ }^{5}$ and S. A. Yaro ${ }^{6}$ \\ $\mathbf{1 , 2 , 4 , 5 , 6}$, Dept of Metallurgical and Materials Engineering, Ahmadu Bello Univ., Zaria, Kaduna State. NiGeria \\ ${ }^{3,}$ Nigerian Institute of Mining AND GeOsCiences, Jos, PlateAu State, NIGERIA \\ E-mail addresses: ${ }^{1}$ asukef@gmail.com, ${ }^{2}$ bellikam@yahoo.com, ${ }^{3}$ rawayau105@gmail.com, \\ 4dungkathomas@gmail.com, ${ }^{5}$ akasim2005@yahoo.com,6yaroaliyu@yahoo.com
}

\begin{abstract}
The chemical and mineralogical characteristics of Gidan Jaja iron ore located in Zurmi Local Governmental Area of Zamfara State was carried out using X-ray Fluorescence (XRF) spectrometer, X-ray Diffractometer (XRD), Scanning Electron Microscope (SEM) and Optical Microscope. The XRF results obtained revealed that Gidan Jaja Iron ore has an average content of $73.79 \% \mathrm{Fe}_{2} \mathrm{O}_{3}, 0.52 \% \mathrm{MnO}_{1} 17.50 \% \mathrm{TiO}_{2}, 0.11 \% \mathrm{CaO}, 0.50 \% \mathrm{Cr}_{2} \mathrm{O}_{3}, 3.84 \% \mathrm{SiO}_{2}, 0.43 \%$ $\mathrm{Al}_{2} \mathrm{O}_{3}, 0.034 \% \mathrm{CuO}, 0.02 \% \mathrm{NiO}, 0.46 \%$ PbO, $2.76 \%$ LOI. Phosphorus and Sulphur were below limit of detection. XRD analysis revealed that the ore contained $56 \%$ IImenite, $34 \%$ Magnetite and $10 \%$ Spinel minerals. Petrographic study using polarized light revealed that the iron bearing minerals are predominant/y IImenite and Magnetite, with minor amount of hematite, spinel and quartz. The results obtained from SEM analysis showed that the iron bearing minerals are separated from other minerals in the ore by smooth grain boundaries. The quality of the ore was compared with ores from other part of Nigeria, and based on the results obtained in this research work, Gidan Jaja iron ore can be classified as high grade, low silica, ilmenite iron ore. Finally combined results from chemical and mineralogical characterization of the iron ore deposit indicated that, the iron ore can be a source of iron ore for use in iron production.
\end{abstract}

Key words: Chemical, Mineralogical, Characterization, Gidan Jaja, Iron ore

\section{INTRODUCTION}

A vibrant iron and steel sector is necessary for the infrastructural and technological development of any modern society. Nigeria is blessed with all the raw materials required for steel development including iron ore, coal, natural gas and limestone [1]. Nigeria has the potentials of becoming a regional economy hub in the West African sub-region, but the economy of the country cannot be strong and vibrant without growth in its iron and steel sector or without the use of iron and steel in the manufacturing sector among others [2].

Iron along with its generic products, is one of the most widely utilized metals in the various sectors of the world's economy. Many factors contribute to this, ranging from the good mechanical properties it possesses to the relative low cost associated with its production. Methods of Iron production include; the blast furnace (BF) route (pig iron) and the direct reduction (DR) route (sponge iron) processes among others. The iron rich ores can be charged directly in its natural form as a raw material into a blast furnace without any further processing. Iron ore that contains lower iron content must be upgraded through beneficiation process before it is charged into the $\mathrm{BF}$ or DR furnaces [3].

Characterization of iron ore is a very important step required before beneficiation and iron production takes place. In this procedure, the quantity, grade or quality, densities, shape, and physical characteristics are determined to allow for appropriate application of technical and economic parameters to support production planning and evaluation of the economic viability of deposits [4].

The most widely available iron-bearing minerals are oxides and consist mainly of hematite $\left(\mathrm{Fe}_{2} \mathrm{O}_{3}\right)$, which

* Corresponding authors, tel: +234-802 - 375- 2977 
is reddish; magnetite $\left(\mathrm{Fe}_{3} \mathrm{O}_{4}\right)$, which is blackish; limonite or bog-iron ore $\left(2 \mathrm{Fe}_{2} \mathrm{O}_{3} \cdot 3 \mathrm{H}_{2} \mathrm{O}\right)$, which is brownish; and siderite $\left(\mathrm{FeCO}_{3}\right)$, which is pale brown. Hematite and magnetite are by far the most common types of iron ore. Pure magnetite contains $72.4 \%$ $\mathrm{Fe}$, hematite $69.9 \% \mathrm{Fe}$, limonite $59.8 \% \mathrm{Fe}$ and siderite $48.2 \% \mathrm{Fe}$ but, since these minerals never occur alone, the main iron $(\mathrm{Fe})$ content of the ores is lower due to other impurities [5].

In Nigeria the most important iron oxides economically are those occurring within the Okene magnetite complex in North Central Nigeria which described the Itakpe Hill deposit. The largest of several similar deposits in the district is hematitemagnetite quartz body, which is ferruginous quartz of the Itakpe types. Recently Geological Survey of Nigeria (GSN) and Raw Materials Research and Development Centre (RMRDC) concluded on mineralogical ground that it represent a replacement of basement gneisses and amphibolites by iron rich solution emanating from nearby granites bodies of the Pan-African older-granite suite. Work to date has outline minerable reserves of $111,400,000$ tonnes grading about $35 \%$ Fe which is easily upgraded and is now being developed for open pit mining to provide feed for the Ajoakuta and Delta Steel Companies [5].

Inventory of some Nigerian iron ores and their chemical composition is presented in Table 1.

Agava, [8] worked on Agbado Okudu iron ore deposit, he reported that, the iron ore contained on the average $38.82 \% \mathrm{Fe}, 49.10 \% \mathrm{SiO}_{2}, 0.05 \% \% \mathrm{P}_{2} \mathrm{O}_{5}$ and $0.03 \% \mathrm{~S}$ and its mineralogical analysis revealed that the iron bearing minerals are predominantly magnetite and hematite. The work index of the ore was found to be $4.32 \mathrm{kWh} / \mathrm{t}$.

KotonKarfe iron ore deposit has also been investigated by Thomas and Yaro, [7]. They concluded that it has iron content of $43.34 \%$ with low amount of silica (10.14\%). From their findings, they reported that the ore contained magnetite, siderite and goethite as the major constituents while hematite is the minor mineral. The work index of Kotonkarfe iron deposit was determined to be $11.33 \mathrm{kWh} /$ tonne and $17.00 \mathrm{kwh} /$ ton for both calcined and uncalcined samples.

Asuke [9] characterized KotonKarfe iron ore and reported that the ore contained mainly magnetite and goethite while siderite, quartz and hematite are present in minor quantities. He also reported that the phosphorus content of the ore is uniformly distributed within the mineral matrix and can be reduced by acidic leaching technique.

Salawu [5] worked on the characterization of Gujeni iron ore deposit and reported that the ore revealed $48.6 \% \mathrm{Fe}, 0.2 \% \mathrm{Mn}, 12.01 \% \mathrm{Ti}, 2.06 \% \mathrm{P}, 0.2 \% \mathrm{~S}$, $6.0 \% \mathrm{Si}, 4.4 \% \mathrm{Al}$ on the average. Mineralogical analysis showed that the ore contained hematite, goethite and rutile in major quantities while, manganese oxide, zincite, zirconium and silicate minerals are present in minor quantities. The work index of the ore was found to be $13.96 \mathrm{kwh} / \mathrm{t}$.

Agava et al., [10] worked on the determination of chemical, mineralogical and liberation size of Ochokochoko iron ore. They reported that the ore contained $50.60 \% \mathrm{Fe}, 17.70 \% \mathrm{SiO}_{2}, 0.05 \% \mathrm{P}_{2} \mathrm{O}_{5}$, and $0.03 \% \mathrm{~S}$ and is predominantly magnetite, hematite, calcite, alumina, and silica. He also reported that the ore can be classified as medium grade and liberated at $-180+125 \mu \mathrm{m}$ sieve size.

The primary objective in this research work is to provide comprehensive data on the chemical and mineralogical characteristics of Gidan Jaja iron ore. These included chemical and mineral phase analysis with the view of finding out and providing useful beneficiation parameters that could possibly be used to develop its process route. The Gidan Jaja iron ore deposit is located in Zurmi Local Government Area of Zamfara State. It is about $50 \mathrm{~km}$ from Kauran Namoda Rail line and $100 \mathrm{~km}$ from Katsina Airport.

The deposit is bounded by Latitudes $12^{\circ} 45^{\prime}$ and $13^{\circ}$ $00 \mathrm{~N}^{\prime}$ and longitudes $6^{\circ} 45^{\prime}$ and $7^{\circ} 00^{\prime} \mathrm{E}$, and its preliminary estimated deposit is over 50 million tonnes [11].

Table 1: Some Nigerian iron ore deposits and their chemical composition

\begin{tabular}{lllllllllll}
\hline Deposits & $\mathrm{K}_{2} \mathrm{O}$ & $\mathrm{CaO}$ & $\mathrm{TiO}_{2}$ & $\mathrm{MnO}$ & $\mathrm{Fe}$ & $\mathrm{MgO}$ & $\mathrm{H}_{2} \mathrm{O}$ & $\mathrm{SiO}_{2}$ & $\mathrm{P}_{2} \mathrm{O}_{5}$ & $\mathrm{~S}$ \\
\hline Itakpe & 0.42 & 0.3 & 0.1 & 0.05 & 36.88 & 0.20 & 1.00 & 44.88 & 0.18 & Trace \\
Ochokochoko & 0.53 & 0.15 & 0.16 & 0.08 & 34.45 & 0.18 & 9.67 & 51.07 & 0.02 & Trace \\
Ajabanako & 0.26 & 0.21 & $\mathrm{Trace}$ & 0.01 & 37.22 & 0.15 & 3.39 & 46.50 & 0.01 & 0.03 \\
Agbado-Okudu & 0.04 & 0.72 & 0.37 & 0.14 & 47.80 & 0.38 & 9.60 & 10.89 & 2.08 & 0.12 \\
Koton Karfe & 0.02 & 0.45 & 0.25 & 0.56 & 48.18 & 0.07 & 6.70 & 5.13 & 2.14 & 0.04 \\
\hline
\end{tabular}

Source: $[6,7]$ 


\section{MATERIALS AND METHODS}

\subsection{Materials and Equipment}

The materials and equipment used in this research include Gidan Jaja Iron ore sample, Laboratory sledge hammer, Laboratory jaw crusher, Ball mill, $\mathrm{X}$ ray florescence (XRF) Machine, X-ray diffractometer (XRD) Machine, Petrological microscope and Scanning electron microscope (SEM).

\subsection{Sample Collection}

Samples of the iron ore were collected from various points on the deposit located at Gidan jaja village, in Zurmi Local Government Area of Zamfara State. Grab method of sampling was adopted in collecting the samples. $60 \mathrm{~kg}$ of the samples were collected at interval of $150 \mathrm{~m}$ apart and $3 \mathrm{~m}$ depth in order to have a representative sample of the ore deposit.

\subsection{Sample Preparation}

The lump sizes of the ore samples were crushed and ball milled. Samples from the four different locations were mixed and homogenized. Coning and quartering method of sampling was used to produce a true representative sample for analyses. The representative sample was used for this investigation.

\subsection{Chemical Compositional Analysis}

The representative sample was taken and analyzed using $X$ ray Florescence (XRF) machine to determine the elemental composition of the ore. The result of the analysis is presented in Table 2 .

\subsection{Mineralogical Analysis of the Ore}

The mineralogy of the ore was determined using both X-ray diffraction (XRD), Scanning Electron Microscopy (SEM) and petrological microscope. This was carried out in order to identify and classify individual mineral, mode of occurrence and the degree of association with other minerals.

\section{RESULTS AND DISCUSSION}

\subsection{Result of Chemical Analysis of Gidan Jaja Iron Ore}

Table 2 present the result of the chemical analysis of Gidan Jaja iron ore using XRF in weight percentages. The ore contains $73.79 \% \mathrm{Fe}_{2} \mathrm{O}_{3}$ and $17.50 \% \mathrm{TiO}_{2}$ as major constituents, with $3.84 \% \mathrm{SiO}_{2}, 0.52 \% \mathrm{MnO}$,
$0.50 \% \mathrm{Cr}_{2} \mathrm{O}_{3}, 0.46 \% \mathrm{PbO}$ and $0.43 \% \mathrm{Al}_{2} \mathrm{O}_{3}$ as minor constituents and $\mathrm{NiO}, \mathrm{CaO}$ and $\mathrm{CuO}$ as traces. Phosphorus and Sulphur were below limit of detection.

The quality of raw iron ores and its viability for commercial exploitation is mainly determined by its chemical composition [3]. Therefore, iron ores should preferably have high Fe contents and low impurity element contents, in order to justify investment during exploitation [4].

Table 2: Chemical composition of Gidan Jaja iron ore

\begin{tabular}{ll}
\hline Oxides composition & $\%$ \\
\hline $\mathrm{SiO}_{2}$ & 3.84 \\
$\mathrm{Al}_{2} \mathrm{O}_{3}$ & 0.43 \\
$\mathrm{CaO}$ & 0.11 \\
$\mathrm{Cr}_{2} \mathrm{O}_{3}$ & 0.50 \\
$\mathrm{TiO}_{2}$ & 17.50 \\
$\mathrm{Fe}_{2} \mathrm{O}_{3}$ & 73.79 \\
$\mathrm{CHO}$ & 0.043 \\
$\mathrm{NiO}$ & 0.02 \\
$\mathrm{MnO}$ & 0.52 \\
$\mathrm{PbO}$ & 0.46 \\
$\mathrm{LOI}$ & 2.76 \\
\hline
\end{tabular}

According to the results obtained from the XRF analysis, it can be pointed out that the Silica and Alumina contents in the iron ore deposit are significantly low but the iron content is high $\mathrm{Fe}_{2} \mathrm{O}_{3}$ $(51.65 \% \mathrm{Fe})$ and thus is superior compared to most of the iron ores from other parts of the country.

\subsection{Mineralogical Analysis of Gidan Jaja Iron Ore}

XRD technique was used to show the mineral phases that are present in the iron ore and provide the quantification of all the phases. The typical result of $\mathrm{X}$-ray diffraction analysis of the iron ore deposit is shown in Figure 1.

From the analysis result, it is clear that the predominant crystalline minerals in the ore sample is ilmenite $\left(\mathrm{FeTiO}_{3}\right)$ and magnetite $\left(\mathrm{Fe}_{2} \mathrm{O}_{3}\right)$ which showed a high phase of $58 \%$ and $32 \%$ respectively with minor amount of $10 \%$ Spinel $\left(\mathrm{MgAl}_{2} \mathrm{O}_{4}\right)$. This is in line with the XRF results and confirms that the ore is a high grade iron ore. 


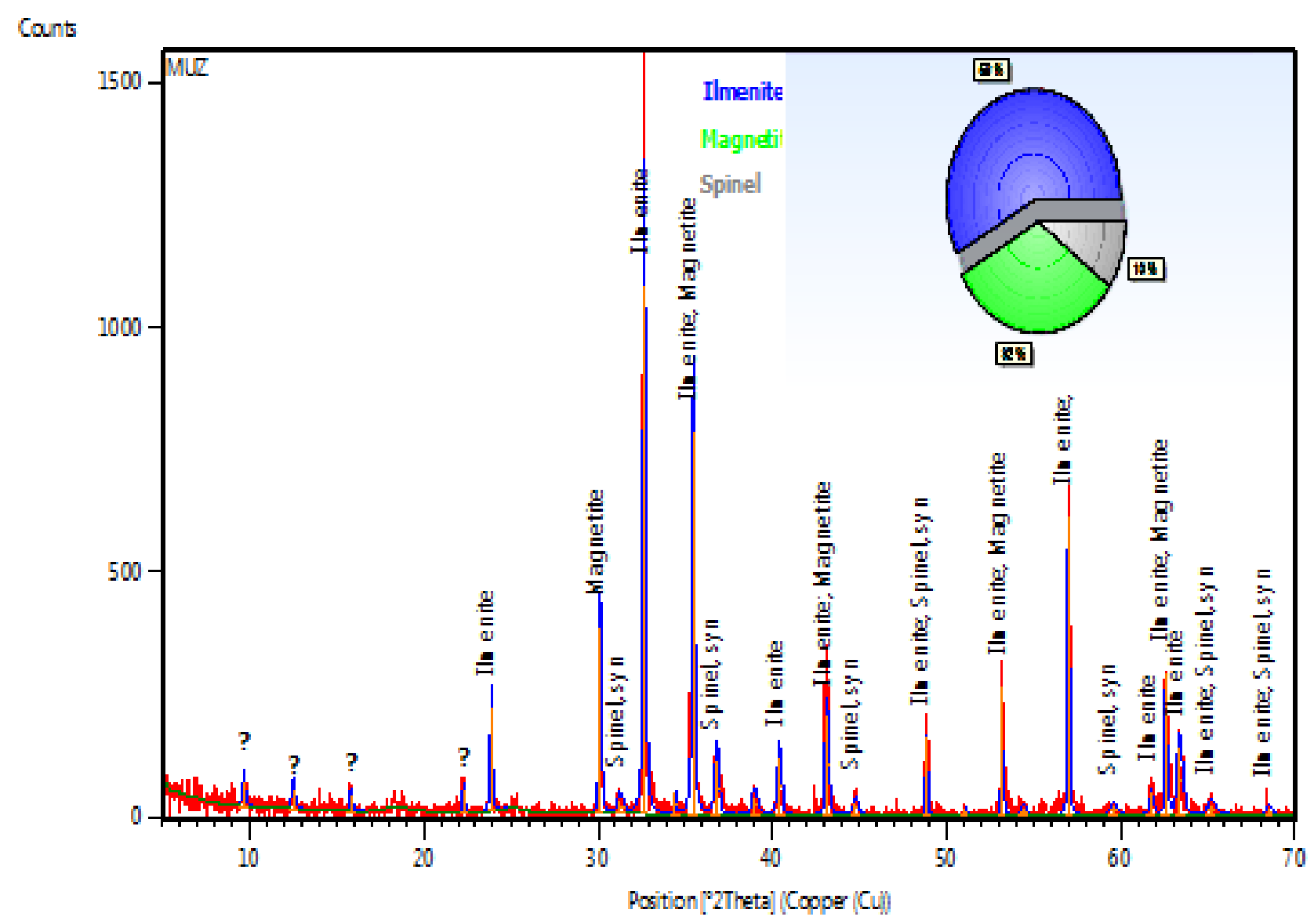

Figure 1: XRD pattern for Gidan Jaja iron ore

Table3: XRD Analysis Result of the Representative Sample

\begin{tabular}{lll}
\hline Mineral name & Chemical formula & \% Composition \\
\hline Ilmenite & $\mathrm{FeTiO}_{3}$ & 58 \\
Magnetite & $\mathrm{Fe}_{3} \mathrm{O}_{4}$ & 32 \\
Spinel & $\mathrm{MgAl}_{2} \mathrm{O}_{4}$ & 10 \\
\hline
\end{tabular}

\subsection{Petrographic Microscopy of Gidan Jaja Iron Ore}

The petrographic analysis was successfully carried out to study and determine the transparent constituents of the representative sample of the iron ore deposit under cross polarized light (XPL). The results of Petrographic microscopy from two different points of the iron ore sample are shown in Figures: $2 \mathrm{a}$ and $2 \mathrm{~b}$.
From the results, four mineral phases were recognized under cross polarized light; the phases are Ilmenite and Magnetite (opaque), Hematite (brown), Spinel (green) and silica (colourless). This result confirmed the result of XRD analysis, which indicated that the predominant minerals present are Ilmenite and Magnetite with subordinate amount of Spinel.

\subsection{Scanning Electron Microscope}

Figure $3 a$ and $3 b$ show the SEM micrographs of the iron ore sample at two different magnifications.

From the results, it is observed that the minerals are separated by grain boundaries, no interlocking of minerals and the mineral particles vary in sizes.This phenomenon indicates that the minerals can be freed from each other during comminution which is in line with earlier reports by Oyeladun et al, [12]. 


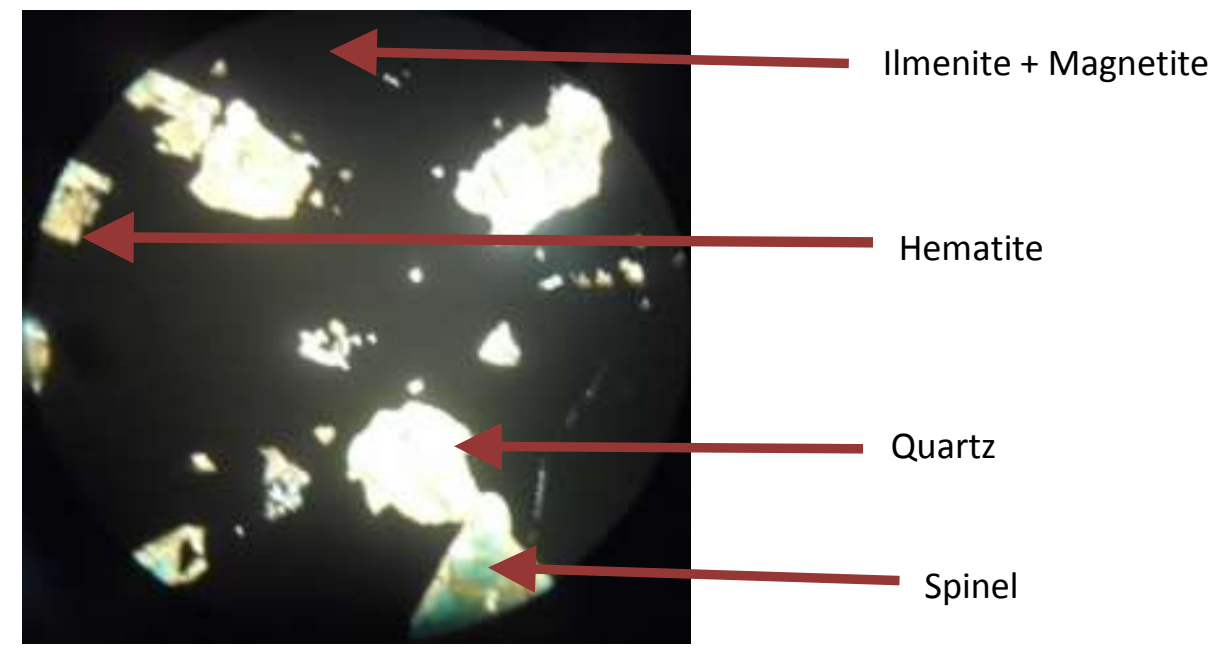

Fig. 2a: Micrograph of Head Sample (X10)

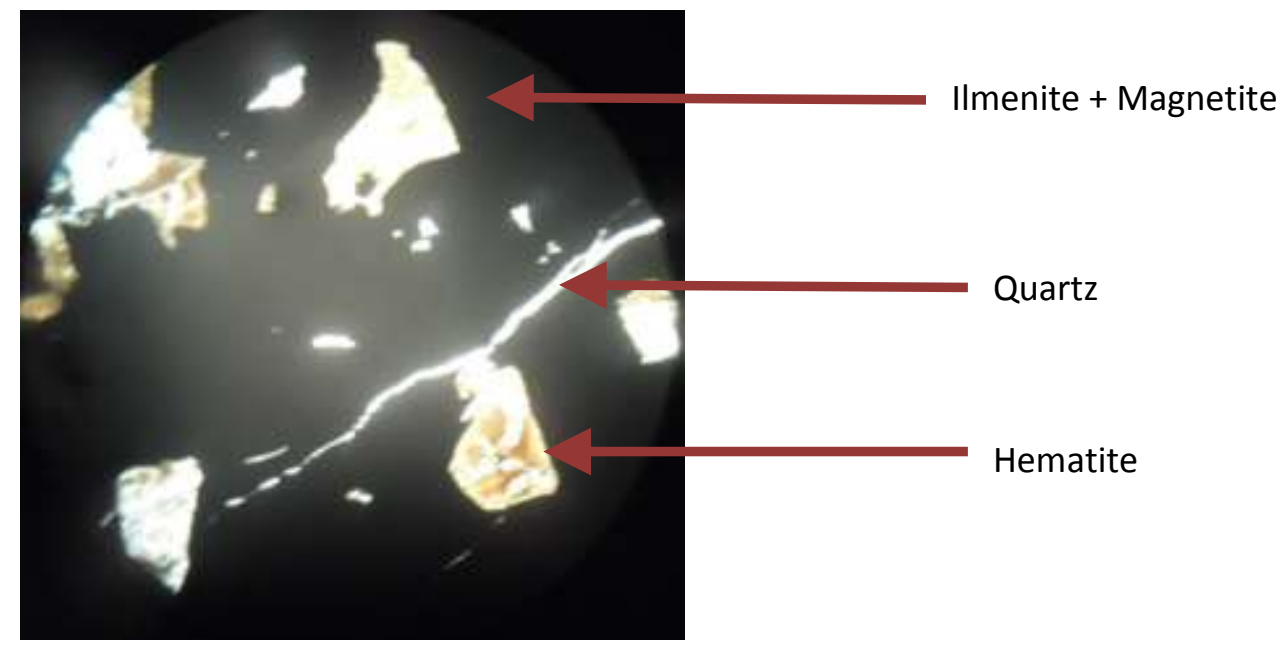

Fig. 2b: Micrograph of Head Sample (X10)
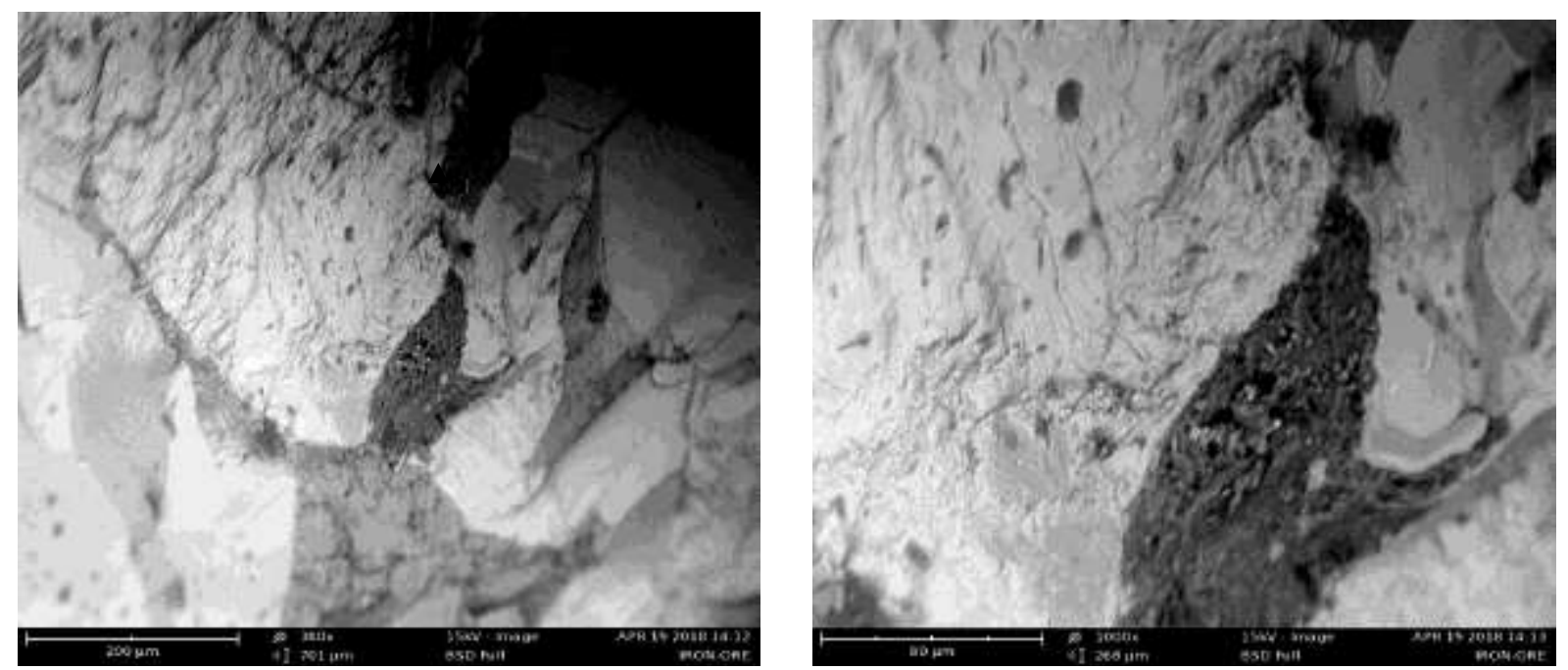

Fig.3a: SEM image of Head Sample (X380)

Fig.3b:SEM image of Head Sample (X1000)

\section{CONCLUSIONS AND RECOMMENDATION} 4.1 Conclusions

The chemical and mineralogical characteristics of

Gidan jaja iron ore deposit of Zurmi L.G.A in Zamfara
State, Nigeria has been carried out and from the results obtained the following conclusions were drawn: 
i. The chemical analysis revealed that the iron ore contains $73.79 \% \mathrm{Fe}_{2} \mathrm{O}_{3}, 0.52 \% \mathrm{MnO}$, $17.50 \% \quad \mathrm{TiO}_{2}, \quad 0.11 \% \quad \mathrm{CaO}, \quad 0.50 \% \quad \mathrm{Cr}_{2} \mathrm{O}_{3}$, $3.84 \% \mathrm{SiO}_{2}, 0.43 \% \mathrm{Al}_{2} \mathrm{O}_{3}, 0.034 \% \mathrm{CuO}, 0.02 \%$ $\mathrm{NiO}, 0.46 \% \mathrm{PbO}$, and $2.76 \%$ LOI. The result indicates that the ore contained more than $50 \% \mathrm{Fe}$ and thus can be regarded as highgrade iron ore with low amount of silica and alumina.

ii. The mineralogical analysis of the ore revealed that the iron bearing minerals are predominantly Ilmenite and Magnetite.

iii. The SEM analysis results revealed that the iron bearing minerals are separated from other minerals contained in the ore by smooth grain boundaries.

iv. From the results obtained, Gidan Jaja iron ore is another potential deposit that can be explored and exploited for usage in iron and steel production.

\subsection{Recommendation}

The liberation size, work index and beneficiation test of the ore should be carried out to establish other parameters that can be used for development of the process route of the ore.

\section{REFERENCES}

[1] Elijah, I. O. "The challenge of the domestic iron and steel production in Nigeria", Greener Journal of Business and Management, Pp. 231, 2013.

[2] Agbu, O. "The iron and steel industry and Nigerias industrialization: Exploring cooperation with Japan. Institute of developing economics", Japan external trade organization. 2007.

[3] Abraham, J. B, Adrey, V. K, Joseph, K. B, Par, G. J. "Characterization of Chemical Composition and Microstructure of Natural Iron Ore from Muko Deposits", ISRN Materials science, Article ID 174803, 9 Pages, 2012.
[4] John, J. K, Alex, M. M, Augustine, B. M, Stephen, K. K. "Characterisation of selected mineral ores in the eastern zone of Kenya: Case study of Mwingi North constituency in Kitui County". International Journal of Mining Engineering and Mineral Processing, 4(1), pp 817, 2015.

[5] Salawu, A. O. "Characterization of Gujeni iron ore deposit, Kaduna state, Nigeria". Department of Metallurgical and Materials Engineering, Ahmadu Bello University, Zaria. M.Sc. Thesis. Unpublished. 2015.

[6] Raw Materials Research and Development Council. Pamphlet of Industrial Raw Materials, Abuja. 2000 Pp. 3-4.

[7] Thomas, D. G. and Yaro, S. A. "The effects of Calcination on the Beneficiation of Koton Karfe Iron Ore". Nigerian Mining Journal. Vol. 5, Nmber 1, pp 49 - 59, 2007.

[8] Agava, A. A. "Upgrading of Agbado-Okudu iron ore using magnetic separation and shaking table techniques", Department of Metallurgical and Materials Engineering, Ahmadu Bello University, Zaria. M.Sc thesis, Unpublished, 2006.

[9] Asuke, F. "Dephosphorization of KotonKarfe iron ore using acidic leaching technique", Department of Metallurgical Engineering, Ahmadu Bello University, Zaria, Phd Thesis, Unpublished, 2014.

[10] Agava, A. A., Murina, R. A., Abdurrahman A. S., Egbe, E. A. P. and Thomas D. G. "Determination of Chemical, Mineralogical Composition and Liberation Size of Ochokochoko Iron Ore, Kogi State", Nigeria. Nigerian Journal of Engineering, Vol. 23, Number 1, pp 77-86, 2016.

[11] Ministry of Mines and Steel Development, "Nigeria Mineral Projects"., Pp. 12, 2012.

[12] Oyeladun, O. A. W., Thomas D. G. and Yaro, S. A. "Determination of the Chemical Composition and the Work Index of Rafin Gabas Chalcopyrite Ore", Nigerian Mining Journal, Vol. 10, Number 1, pp37-44, 2012. 